Canadian Journal of Applied Linguistics

Revue canadienne de linguistique appliquée

\title{
Knowledge of Greek and Latin Roots is Related to Reading Comprehension among French-Speaking Sixth Graders
}

\section{Kathleen Whissell-Turner et Anila Fejzo}

Volume 24, numéro 3, automne 2021

URI : https://id.erudit.org/iderudit/1084810ar

DOI : https://doi.org/10.37213/cjal.2021.30473

\section{Aller au sommaire du numéro}

\section{Éditeur(s)}

University of New Brunswick

\section{ISSN}

1920-1818 (numérique)

Découvrir la revue

\section{Citer cet article}

Whissell-Turner, K. \& Fejzo, A. (2021). Knowledge of Greek and Latin Roots is Related to Reading Comprehension among French-Speaking Sixth Graders. Canadian Journal of Applied Linguistics / Revue canadienne de linguistique appliquée, 24(3), 61-78. https://doi.org/10.37213/cjal.2021.30473

\section{Résumé de l'article}

A la fin de l'école primaire, les élèves sont confrontés à des textes explicatifs connus pour leur forte proportion de mots du vocabulaire académique spécifiques à un domaine. Ces mots comprennent généralement des racines grecques ou latines dans leur structure interne. Des découvertes récentes ont montré que la connaissance des racines grecques et latines est liée à la compréhension de la lecture. Cependant, aucune étude n'a investigué une telle relation dans un contexte francophone. Par conséquent, la présente étude a cherché à mesurer la relation entre les racines grecques et latines et la compréhension de la lecture chez les élèves francophones de 6e année du primaire. Pour ce faire, 40 participants ont été soumis à une tâche expérimentale sur la connaissance des racines grecques et latines et à un sous-test standardisé de compréhension de la lecture. Des variables liées à la compréhension de la lecture telles que la conscience morphologique, l'étendue du vocabulaire, la fluidité de la lecture des mots, la compréhension orale et la mémoire de travail ont également été mesurées. Les résultats ont montré que la connaissance des racines grecques et latines prédisait de manière significative la variation de la compréhension de la lecture. Cet article discute des implications scientifiques et éducatives de cette découverte.
Copyright (C) Kathleen Whissell-Turner, Anila Fejzo, 2021

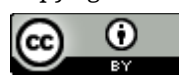

Ce document est protégé par la loi sur le droit d'auteur. L'utilisation des services d'Érudit (y compris la reproduction) est assujettie à sa politique d'utilisation que vous pouvez consulter en ligne.

https://apropos.erudit.org/fr/usagers/politique-dutilisation/ 


\title{
Knowledge of Greek and Latin Roots is Related to Reading Comprehension among French-Speaking Sixth Graders
}

\author{
Kathleen Whissell-Turner \\ Université du Québec à Montréal \\ Anila Fejzo \\ Université du Québec à Montréal
}

\begin{abstract}
By the end of primary school, students are confronted with expository texts known for their high proportion of domain-specific academic vocabulary words. These words usually comprise Greek or Latin roots in their internal structure. Recent findings showed that knowledge of Greek and Latin roots is related to reading comprehension. However, no study has investigated such a relationship in a francophone context. Therefore, the present study sought to measure Greek and Latin roots' relation to reading comprehension among French $6^{\text {th }}$ graders. To do so, 40 participants were administrated an experimental task on Greek and Latin roots knowledge and a reading comprehension standardized subset test. Variables related to reading comprehension, such as morphological awareness, vocabulary breadth, word reading fluency, oral comprehension, and working memory were also measured. Results showed that knowledge of Greek and Latin roots significantly predicted variation of reading comprehension. This paper discusses scientific and educational implications of this finding.
\end{abstract}

\section{Résumé}

À la fin de l'école primaire, les élèves sont confrontés à des textes explicatifs connus pour leur forte proportion de mots du vocabulaire académique spécifiques à un domaine. Ces mots comprennent généralement des racines grecques ou latines dans leur structure interne. Des découvertes récentes ont montré que la connaissance des racines grecques et latines est liée à la compréhension de la lecture. Cependant, aucune étude n'a investigué une telle relation dans un contexte francophone. Par conséquent, la présente étude a cherché à mesurer la relation entre les racines grecques et latines et la compréhension de la lecture chez les élèves francophones de $6^{\mathrm{e}}$ année du primaire. Pour ce faire, 40 participants ont été soumis à une tâche expérimentale sur la connaissance des racines grecques et latines et à un sous-test standardisé de compréhension de la lecture. Des variables liées à la compréhension de la lecture telles que la conscience morphologique, l'étendue du vocabulaire, la fluidité de la lecture des mots, la compréhension orale et la mémoire de travail ont également été mesurées. Les résultats ont montré que la connaissance des racines grecques et latines prédisait de manière significative la variation de la compréhension de la lecture. Cet article discute des implications scientifiques et éducatives de cette découverte. 


\section{Knowledge of Greek and Latin Roots is Related to Reading Comprehension among French-Speaking Sixth Graders}

\section{Reading Comprehension, Morphological Awareness, and Domain-Specific Academic Vocabulary}

Reading comprehension is known to be a complex ability requiring the interaction of various components regulated by working memory (Kintsch, 1998). Basically, in the Simple View of Reading (Gough \& Tunmer, 1986), reading comprehension is achieved by the interaction of word identification and oral comprehension. Also, a convincing number of studies have shown that metalinguistic abilities such as phonological awareness and morphological awareness are important predictors of reading comprehension. Indeed, phonological awareness, which is the ability to perceive and manipulate the smallest units of sounds in a target language (Kuo \& Anderson, 2006), is strongly related to word reading in the early grades (e.g., National Reading Panel [NRP], 2000; Perfetti, 1985). Further, morphological awareness is a more accurate predictor of reading abilities in the intermediate grades (Deacon et al., 2017). Morphological awareness is an ability focussing on the smallest meaningful units of one's language, called morphemes (e.g., there are three morphemes in un-chang-ed) (Kuo \& Anderson, 2006). Even though morphological awareness has been found to be related to reading comprehension as early as the first grades, its contribution is greater by the end of elementary school (Kirby et al., 2012; Nagy et al., 2006; Singson et al., 2000). During this period, children encounter a large number of unknown morphologically complex words, in other words, comprised of two or more morphemes, in their schoolbooks. It is estimated that the meaning of $60 \%$ of these words can be entirely or partially deduced by chunking them into morphemes (Nagy \& Anderson, 1984). Effectively, the meaning of a complex word like incoherently can be calculated from the meaning of its morphemes in (not) + coherent + ly (way), acting in a not coherent way.

Moreover, the quality of reading comprehension is related to precise and highquality representations of words according to reading models (Perfetti, 2007; Perfetti \& Stafura, 2014). These models postulate that comprehension is progressively built by processing the exact and appropriate meaning of the words. To retrieve the exact meaning of the word, one needs to encode high-quality word representations. Accurate phonological, orthographic, grammatical, and semantic representations of morphemes (roots, prefixes, and suffixes) are thought to help the reader to build accurate representations of morphologically complex words comprised of them. Consequently, the contribution of morphological awareness to reading comprehension is better understood as a predictor of word identification and listening comprehension (Levesque et al., 2017).

Elsewhere, studies interested in the contribution of morphological awareness in reading comprehension at various grades, in English (e.g., Carlisle, 2000; Deacon et al., 2017; Kieffer \& Box, 2013; Nagy et al., 2006; Nunes et al., 2012; Ucelli et al., 2015) and in French (e.g., Casalis \& Louis-Alexandre, 2000), have found that it impacts reading comprehension beyond the impact of other variables such as word reading, vocabulary, non-verbal intelligence and phonological awareness (e.g., Carlisle, 2000; Deacon et al., 2017; Kieffer \& Box, 2013; Nunes et al., 2012). The role of morphological awareness may be more important for the comprehension of expository texts where the word knowledge 
becomes more crucial for text comprehension (Fazio \& Gallagher, 2014; Nagy et al., 1987). Indeed, these texts are comprised of domain-specific academic vocabulary (Henry, 2010). Although infrequent in common usage, this type of vocabulary is frequent in content-area literacy (Fazio \& Gallagher, 2014). It occurs specifically in a defined subject area (e.g., biology, geography) and is typically used to refer to precise concepts as photosynthesis or geothermal energy (Baumann \& Graves, 2010). Given that lack of word knowledge as little as $2 \%$ of the total of words in a text entails comprehension failure (Nation, 2006; Observatoire National de la Lecture [ONL], 2000), limited knowledge of this specific vocabulary may lead to misconceptions, which affect academic learning (Blachowicz \& Obrochta, 2005).

Domain-specific academic vocabulary encountered in expository texts is often characterized by a complex internal structure, often formed by at least two morphemes. Usually, a domain-specific academic vocabulary word benefits from the composition of a Greek or Latin root (Nagy \& Townsend, 2012). For example, the word geothermal is composed of two Greek roots, geo and therm, which respectively mean earth and heat (Cellard, 2013), and the suffix -al. The knowledge of these roots may allow students to infer totally or partially the meaning of a domain-specific academic word (Henry, 2010). For that, children need to have developed analytical abilities and know the meaning of composing Greek or Latin roots, in other words, have developed morphological awareness.

\section{Knowledge of Greek and Latin Roots and Reading Comprehension}

Greek and Latin roots are very frequent in academic texts (Bertrand, 2011; Rasinski et al., 2008). Indeed, in English expository texts, $60 \%$ of words are of Greek or Latin origin (Green, 2015). From middle to high school, this amount increases to 80\% (Bar-ilan \& Berman, 2007). Unfortunately, to our knowledge, no data is available for French expository texts. However, French is a Latin-based language in addition to having many derived words from Greek roots (Bertrand, 2011). Effectively, nearly $90 \%$ of French vocabulary originates from Latin or Greek (Bertrand, 2011), a higher proportion than English vocabulary which is situated between $60 \%$ and $75 \%$ (Rasinski et al., 2008; Stockwell \& Minkova, 2001). Therefore, it is relevant to expect the presence of a high proportion of words composed of Greek and Latin roots in expository texts in French schoolbooks.

Knowledge of Greek and Latin roots allow students to assimilate the meaning of plenty of other words formed with the same root (Palumbo et al., 2015). Indeed, morphological families formed with Greek and Latin roots can account for between five and twenty words (Rasinski et al., 2008). For example, knowledge of the Greek root $h y d r(o)$, which means water, allows students to infer the meaning of many words such as hydroplane, hydraulic, hydrate, hydration, hydroelectricity, hydrophobia, hydrography, hydrology, hydroponics, and so forth. This morphological analysis grants students with autonomy in their reading. Despite the high potential of this morphological strategy, limited time is devoted to such lexical strategies to deduce the meaning of unknown words in francophone classrooms. A recent study was conducted on declared practices of vocabulary instruction among 34 elementary teachers in Montreal, Quebec (Grade 1 to Grade 6, Anctil et al., 2018). It was discovered that less than $10 \%$ of vocabulary 
instruction, which was by itself relatively limited, was consecrated to lexical strategies to deduce the meaning of unknown words, such as morphological analysis.

Furthermore, inferring the meaning of unknown words by means of Greek and Latin roots could be an effective strategy, since the meaning of those roots refers to common vocabulary usually understood by students. More specifically, even if the domainspecific academic vocabulary composed of Greek and Latin roots refers to an abstract concept (Nagy \& Townsend, 2012), common vocabulary is often applied to designate the meaning of each root (Rasinski et al., 2008). For instance, our previous example, geothermal, could be a complex concept for $6^{\text {th }}$-grade students. Nevertheless, referring to the common vocabulary earth and heat, of the roots geo and therm respectively, may help children to deduce the meaning of geothermal. Consequently, Greek and Latin roots could facilitate students' reading comprehension by allowing them to access the meaning of unknown words composed of known roots (Crosson \& Moore, 2017).

However, little research has investigated the relationship between the knowledge of Greek and Latin roots and reading comprehension. Even though students as young as first graders are sensitive to Greek and Latin roots' meaning after a morphological instruction (Freeman et al., 2019), most studies have been conducted with middle-grade and high school English-speaking students. Crosson and McKeown (2016) measured the effects on reading comprehension of a morphological instruction based on Greek and Latin roots. This quasi-experimental study took place among five $6^{\text {th }}$-grade classrooms in the United States. Two groups formed the control group while the remaining groups received a twoyear intervention on Greek and Latin roots taught by their teacher. A total of 18 roots in $6^{\text {th }}$ grade and 16 roots in $7^{\text {th }}$ grade was taught to students. Results indicated that students who received the morphological instruction based on Greek and Latin roots were better at retrieving the meaning of roots within unknown words. Students were also better than their control peers in understanding a sentence where an unknown word formed by a Greek or Latin root was crucial to the understanding of the sentence. The training helped students to develop morphological analysis strategies, allowing them to transfer it to sentence comprehension (Crosson \& McKeown, 2016).

Also, Crosson et al. (2019) conducted an intervention study where two conditions were provided and counterbalanced. The comparison condition was a robust vocabulary instruction (RAVE: Robust Academic Vocabulary Encounters). The second condition merged this instruction with explicit morphological Latin roots' instruction. Results showed that both conditions led to the development of a better understanding of the meaning of academic vocabulary. However, morphological analysis development with unknown words benefited only from Latin roots instruction. In sum, Latin roots' instruction allowed students to better understand a sentence formed by an unknown word, but, as the authors mentioned, it is risky to assume that this instruction would also have long-term effects on reading comprehension since these effects were not measured (Crosson et al., 2019).

Taken together, these findings suggest a relationship between knowledge of Greek and Latin roots and reading comprehension in an English linguistic context. Focusing on morphological awareness of roots, particularly roots of Greek and Latin origin highly prevalent in expository texts, might be an interesting avenue, especially since most texts presented to middle-school students are expository (Daniels, 2002). To our knowledge, no study has investigated this relationship in a French linguistic context. The higher 
proportion of words comprised of Greek and Latin roots in this linguistic context leads us to believe that they must be highly represented in expository texts, consequently, their knowledge would influence reading comprehension (Perfetti \& Stafura, 2014). However, one must assume that the higher proportion of these words in French may lead to a better understanding of these words by the students. Consequently, the relationship between the Greek and Latin roots' knowledge and reading comprehension may be different in a French context. Thus, we sought to examine the relationship between the knowledge of Greek and Latin roots and reading comprehension among French-speaking $6^{\text {th }}$ graders.

\section{Method}

\section{Participants}

Participants were 40 French-speaking $6^{\text {th }}$ graders $(18$ girls; mean age $=12: 1)$ recruited from four classrooms of a francophone public school on the South Shore of Montreal. According to parents' answers on the demographic questionnaire, six students spoke another language than French at home (English, Serbian or Portuguese). Moreover, teachers informed the researcher that 13 students displayed at least one learning disability or learning disorder (e.g., dyslexia, dyspraxia, dysorthographia). A Mann-Whitney test revealed that scores of reading comprehension from students speaking French at home were not significantly different from those of second-language children (Mann-Whitney $=$ .592). Also, there was no significant difference between scores of reading comprehension from students with or without learning disabilities (Mann-Whitney $=.135$ ). Therefore, all students remained part of the sample.

\section{Measures}

\section{Knowledge of Greek and Latin Roots}

To our knowledge, no existing test measures the knowledge of Greek and Latin roots among francophone $6^{\text {th }}$ graders, nor among francophone students regardless of the grade. Therefore, an experimental multiple-choice group format test was developed for this study. Forty frequent and rare words composed of Greek and Latin roots were chosen for this test. Specifically, it was comprised of 10 frequent words and 10 low-frequency words formed with a Latin root, and 10 frequent words and 10 low-frequency words formed with a Greek root. Their frequency is retrieved from the MANULEX database (Lété et al., 2004) which indexes words from students' textbooks from CP to CM2 (equivalent to $1^{\text {st }}$ grade to $5^{\text {th }}$ grade in Quebec). Since the European French educational system does not account for a $6^{\text {th }}$ grade at the elementary school level, data were retrieved based on their middle schools' grades (CE2 to CM2; i.e., $3^{\text {rd }}$ to $5^{\text {th }}$ grade). If the frequency of the orthographic form (U) in this database was higher than 10 occurrences per one million words, the word was considered frequent, and rare if it was lower than 10 (Casalis \& Janiot, 2009). Means and standard derivations were also calculated to make sure that frequent words composed of Latin roots $(M=33.28, S D=20.41)$ and Greek roots $(M=31.37, S D=20.22)$ were comparable $(t=0.212 ; p=0.834)$. Those analyses were also applied to rare words composed of Latin $(M=2.83, S D=2.70)$ and Greek roots $(M=2.34, S D=2.54)$, and the $t$-test results were, again, nonsignificant $(t=0.419 ; p=0.680)$. 
Items were presented in context-free sentences to prevent students to answer by means of context clues (e.g., Dans le mot biologie, que signifie la partie du mot bio-? / In the word biology what does that word part bio- means?). Children had to choose one of the four answers with one obviously representing the correct meaning (e.g., vie / life). Based on the model of morphological knowledge (Kuo \& Anderson, 2006), the distractors were comprised of 1) a wrong answer due to phonological similarity (e.g., billot de bois / log of wood); 2) a wrong answer due to orthographic similarity (e.g., biais / bias); and 3) wrong answer retrieved from the lexical field of the item (e.g., science). Answers were randomly distributed for each item.

E.g., Dans le mot biologie que signifie la partie du mot bio-? a. Science $b$. Vie $c$. Billot de bois $d$. Biais

The first version of the test was validated among students of another $6^{\text {th }}$-grade classroom, also from the South Shore of Montreal. After that validation, minor changes were made. For example, items that were too easy or too difficult for the population were replaced while preserving the frequency index.

For the administration procedure of this test, students are asked to circle one answer for each item. One point was assigned for a correct answer and zero for a wrong answer. Internal validity was strong $(\alpha=.962)$.

\section{Reading Comprehension}

Wechsler's (2008) subtest from WIAT-II was used to measure reading comprehension. This subtest was originally individual but was modified to a group format to optimize data gathering. While performing this cloze task, students were asked to read two short texts (respectively 208 and 220 words) followed by four and five comprehension questions. The answers were given in writing form, instead of orally as the original procedure recommends. The original data weighting was used to correct this test, which makes two points for a complete answer and one point for a partial one. No point was made for a wrong answer.

In addition to the main variables (i.e., knowledge of Greek and Latin roots, and reading comprehension), control variables were measured because of their high interaction in reading ability, based on theoretical models of reading comprehension (Kintsch, 1998; Gough \& Tunmer, 1986; Tunmer \& Chapman, 2012; Perfetti, 2007; Perfetti \& Stafura, 2014). Indeed, considered like pillars of reading comprehension, word identification and oral comprehension tests were administered (Gough \& Tunmer, 1986). For its central role in reading comprehension (Tunmer \& Chapman, 2012; Perfetti \& Stafura, 2014), vocabulary was also administered as a control variable, as well as morphological awareness, an ability providing high-quality lexical representation, highly influencing reading comprehension (Bowers et al., 2010). The last control variable is working memory, an omnipresent variable in reading comprehension (Kintsch, 1998).

\section{Morphological Awareness}

Morphological awareness was measured using Fejzo's test (2016) which is divided into three tasks: word derivation, base extraction, and non-word derivation. For the word 
derivation task, students had to fill in the blank with a derived word for 7 sentences (e.g., Celui qui manque de respect envers les autres est [irrespectueux] / One whose lack of respect towards others is [disrespectful]). In the base extraction, which was comprised of 10 items, children had to provide the base of the derived word presented previously in bold (e.g., L'eau est inodore. Cela veut dire qu'elle n'a pas d' [odeur]./ Water is odourless. This means that it has no [odor].). For the last task, students were asked to fill the blank with a derived non-word (e.g., Quand on dale encore une fois, on [redale] / When one dales another time, one [redales].). One point was given for each correct answer. The internal reliability for this test was high $(\alpha=.86)$.

\section{Vocabulary Breadth}

The Échelle de vocabulaire en images Peabody (ÉVIP; Bianco et al., 2014), a French version of Peabody Picture Vocabulary Test (PPVT; Dunn et al., 1993), was groupadministered to test vocabulary breadth. Each of the 40 isolated word items was read out loud to students by the researcher. Students had to identify the image among four that corresponded to the pronounced word. One point was given for each word matched to the correct image.

\section{Oral Comprehension}

A subtest from the battery Évaluation clinique des notions langagières fondamentales (CELF; Wiig et al., adapt. Boulianne, \& Labelle, 2009) was slightly modified to measure oral comprehension among $6^{\text {th }}$ graders. Instead of initial individual testing, paragraphs were previously recorded to allow for a group-administered test. Students were asked to give a written answer to 5 comprehension questions after each of the 3 passages were heard, instead of the standard oral response. Comprehension questions were read out loud by the researcher and were repeated if requested. However, the recording of the passage could be heard only once, as the initial protocol recommended. One point was attributed for each correct answer, according to the initial protocol. No point was granted for an incomplete or incorrect answer.

\section{Word Identification}

Word identification informs word reading fluency (accuracy and rapidity). To that end, word set A of Batterie d'évaluation du langage écrit et de ses troubles (BÉLEC; Mousty et al., 1994) was used. This test comprises 72 words, 36 short words and 36 long words. For the purpose of this study, only the long words were considered. This decision can be explained by the fact that longer words are usually polymorphemic, a shared characteristic with Greek and Latin roots' words. In this word identification task, students were asked to read lists of words rapidly and accurately. Their reading was recorded to calculate the score. The total reading time was divided by the score of words read correctly, which accounted for the word reading fluidity score. 


\section{Working Memory}

Working memory was measured by a subtest of the battery Évaluation clinique des notions langagières fondamentales (CELF; Wiig et al., 2009). Students in this individual task had to repeat number sequences (from 2 to 8 items $\times 2$ attempts $=16$ series) in the correct order, and then in reverse order (from 2 to 7 items x 2 attempts $=14$ series). Series are presented in increasing difficulty. Students received one point for every entire sequence repeated correctly. Testing stopped when students missed the two attempts of the same item. According to the battery protocol, inter-item reliability for 11 to 12 -years-old children is .87 (Wiig et al., 2009).

\section{Procedure}

Since the present study aims to verify the relationship between the knowledge of Greek and Latin roots and reading comprehension among $6^{\text {th }}$-grade students, no intervention was provided. All tests were administered over a 4-week period, from midMay to mid-April. Tests were administered in three morning sessions to control for the biases related to students' end-of-day fatigue.

In the first one-hour session, students performed two group-format tests: reading comprehension and morphological awareness. In the second one-hour session, the test measuring the knowledge of Greek and Latin roots, as well as the vocabulary test, were administered to the group class. To minimize decoding skill effects, the items in the morphological awareness task and the Greek and Latin roots knowledge test were read out loud by the researcher. In the third 30-minute session, oral comprehension was administered collectively. It was followed by two individual tests, word identification and working memory. For the latter, students individually joined the researcher in a quiet room near the classroom to perform those two tests of just over five minutes. Test administration order in each session was designed after considering students' cognitive effort: each session started with the most demanding test.

\section{Results}

The purpose of the study was to examine Greek and Latin roots' relationship to reading comprehension among French $6^{\text {th }}$ graders. To do so, descriptive (see Table 1 ), correlational (see Table 2), and hierarchical regression analyses (see Tables 3 and 4) were performed.

\section{Descriptives}

Table 1 shows the means and standard deviations on all measures for the entire sample. As shown, the sample mean for reading comprehension is $12.55 / 18$ points, a $70 \%$ success rate. The score for Greek and Latin roots knowledge of 22.63/40 points as the mean represent a $57 \%$ success rate. A high standard deviation $(S D=5.21)$ can also be noted for this measure, which suggests a disparity between the results of the students. Control variable results are generally high. 
Table 1

Means and Standard Deviations of All Measures

\begin{tabular}{lccc}
\hline \multicolumn{1}{c}{ Measures } & $\begin{array}{c}\text { Number } \\
\text { of items }\end{array}$ & \multicolumn{2}{c}{$6^{\text {th }}$ graders $(\mathrm{n}=40)$} \\
\cline { 3 - 4 } & & Mean $(M)$ & $\begin{array}{c}\text { Standard deviation } \\
(S D)\end{array}$ \\
\cline { 3 - 4 } & & 12 years, 1 month & 0,39 \\
Age & 18 & 12,55 & 2,94 \\
Reading comprehension & 40 & 22,63 & 5,21 \\
Greek and Latin roots & & & \\
$\quad$ knowledge & 25 & 17,50 & 2,57 \\
Morphological & & 30,82 & 3,50 \\
$\quad$ awareness & 40 & 13,15 & 1,81 \\
Vocabulary breadth & 15 & 2,15 & 1,00 \\
$\begin{array}{l}\text { Oral comprehension } \\
\text { Long word reading }\end{array}$ & 36 & & \\
$\quad \begin{array}{l}\text { fluency } \\
\text { (seconds/words }\end{array}$ & & & 2,72 \\
$\quad$ correctly read) & & 13,35 & \\
Working memory & 30 & & \\
\hline
\end{tabular}

Results from Table 2 indicate that reading comprehension is significantly and moderately correlated with Greek and Latin roots knowledge $(r=.46, p<.01)$, with vocabulary breadth $(r=.54, p<.01)$, and with working memory $(r=.46, p<.01)$. Long word reading fluency is negatively correlated with reading comprehension, but less strongly $(r=-.38, p<.05)$. There were no significant correlations between reading comprehension and morphological awareness $(r=.16, p=.325)$, and neither with oral comprehension $(r=.28, p=.081)$.

\section{Table 2}

Correlations among Variables for All Measures of $6^{\text {th }}$ Graders

\begin{tabular}{lcccccc}
\hline Measures & 1 & 2 & 3 & 4 & 5 & 6 \\
\hline Reading comprehension & - & & & & \\
Knowledge of Greek and & $.460^{* *}$ & - & & & \\
Latin roots & & & & & \\
Morphological awareness & .160 & $.357^{*}$ & - & & \\
Vocabulary breadth & $.541^{* *}$ & $.497^{* *}$ & $.318^{*}$ & - & \\
Oral comprehension & .279 & .191 & $.364^{*}$ & .264 & - & \\
Long word reading fluency & $-.380^{*}$ & -.282 & -.195 & -.221 & -.034 & - \\
Working memory & $.460^{* *}$ & $.425^{* *}$ & $.370^{*}$ & $.391^{*}$ & $.375^{*}$ & -.090 \\
\hline
\end{tabular}

Note. $\mathrm{n}=40$

$* p<.05$

$* * p<.01$ 
Meanwhile, knowledge of Greek and Latin roots was significantly correlated with morphological awareness $(r=.36, p<.05)$, vocabulary breadth $(r=.54, p<.01)$, and working memory $(r=.43, p<.01)$. Other measures, oral comprehension and long word reading fluency were not significantly correlated with the sample's knowledge of Greek and Latin roots.

Overall, these results indicate significant correlations between knowledge of Greek and Latin roots and reading comprehension among francophone $6^{\text {th }}$ graders $(r=.460, p<$ $.01)$. Furthermore, these results provide insight that working memory and vocabulary breadth are non-negligible variables in the relationship between our main variables, especially since vocabulary breadth represents the greatest correlation with both reading comprehension $(r=.541, p<.01)$ and the knowledge of Greek and Latin roots $(r=.497, p$ $<.01)$.

\section{Predictive Value of the Knowledge of Greek and Latin Roots to Reading Comprehension}

In order to measure the predictive value of the knowledge of Greek and Latin roots with regards to $6^{\text {th }}$ graders' reading comprehension, a hierarchical regression was performed. As suggested by the literature, we entered only variables significantly related to reading comprehension in the hierarchical regression analysis (Howell, 2008). We first entered in the equation the independent variable, the knowledge of Greek and Latin roots, and then control variables that were significantly correlated to reading comprehension: vocabulary breadth, long words reading fluency and working memory. Table 3 presents the results of this analysis.

\section{Table 3}

Predictive Value of the Knowledge of Greek and Latin Roots to Reading Comprehension

Path Reading comprehension

Model 1

$\frac{\Delta \mathrm{R}^{2}}{.211^{* *}}$

Knowledge of Greek and Latin roots

$.460 * *$

Model 2

$.268 *$

Vocabulary breadth

Long words reading fluency

$-.275^{*}$

Working memory .268

\begin{tabular}{l} 
Total $\mathrm{R}^{2}$ \\
\hline Note. $\mathrm{n}=40$ \\
$* p<.05$ \\
$* * p<.01$
\end{tabular}

Results from Table 3 show that the knowledge of Greek and Latin roots explains $21 \%$ of reading comprehension variance $(\boldsymbol{\beta}=.460, p<.01)$ when entered first in the model. Control variables, namely vocabulary breadth, long words reading fluency and working memory accounted for $28 \%$ of reading comprehension variance. 


\section{Contribution of the Knowledge of Greek and Latin Roots to Reading Comprehension}

Thereafter, a second hierarchical regression was executed in order to isolate the unique contribution of the knowledge of Greek and Latin roots to reading comprehension. Control variables correlated with reading comprehension (i.e., vocabulary breadth, long words reading fluency and working memory) were first entered in the model of the regression, and further knowledge of Greek and Latin roots was entered in the model. Table 4 provides the results obtained from this second hierarchical regression.

\section{Table 4}

Regression Model Results of Greek and Latin Roots Predicting Reading Comprehension

\begin{tabular}{lcc}
\hline Path & \multicolumn{2}{c}{ Reading comprehension } \\
\cline { 2 - 3 } Model 1 & $\Delta \mathrm{R}^{2}$ & $\beta$ \\
\cline { 2 - 3 } Vocabulary breadth & $.465^{* *}$ & $.381^{*}$ \\
Long words reading fluency & & $-.299^{*}$ \\
$\quad$ Working memory & & $.304^{*}$ \\
Model 2 & & .151 \\
$\quad$ Knowledge of Greek and Latin roots & .015 & \\
Total R & & .479 \\
\hline
\end{tabular}

Note. $\mathrm{n}=40$

* $p<.05$

$* * p<.01$

The variance of reading comprehension explained by the model increased by $1.5 \%$ by adding Greek and Latin roots knowledge, for a total of $47.9 \%$, but the magnitude of this knowledge was not significant $(\boldsymbol{\beta}=.151, p=.343)$.

To sum up, the hierarchical regression models provide an answer to the research question by revealing knowledge of Greek and Latin roots account for $21.1 \%$ of the variance in francophone $6^{\text {th }}$ graders' reading comprehension when it is entered first in the regression model. However, this knowledge had no unique contribution to reading comprehension when entered last into the model.

\section{Discussion}

The goal of the present study was to examine the relationship between the knowledge of Greek and Latin roots and reading comprehension among francophone $6^{\text {th }}$ graders. For that, measures of knowledge of Greek and Latin roots, reading comprehension, and predictive variables of reading comprehension such as morphological awareness, reading fluency, oral comprehension, working memory and vocabulary breadth were administered. Results showed a moderately strong relationship between the knowledge of Greek and Latin roots and reading comprehension $(r=.46, p<.01)$. Also, the knowledge of Greek and Latin roots predicted $21.1 \%$ of reading comprehension variance when entered first in the model of regression.

These results corroborate those obtained in the English-speaking context (Crosson \& McKeown, 2016; Crosson et al., 2019) suggesting a relationship between the knowledge 
of Greek and Latin roots and reading comprehension, especially sentence comprehension. Our finding supports the hypothesis that the knowledge of Greek and Latin roots is related to reading comprehension from middle grades due to the increasing number of words composed of those roots (Henry, 2010; Padak et al., 2008).

However, knowledge of Greek and Latin roots no longer had a predictive value of reading comprehension when it was entered in the last step of the regression model. This lack of a unique contribution could be explained, from a statistical point of view, by the fact that it may share its predictive value of reading comprehension with another variable previously entered in the regression model. Indeed, vocabulary, which was entered in the first step, was significantly correlated with knowledge of Greek and Latin roots $(r=.497, p$ $<.01)$. As Greek and Latin roots maintain their meanings from one word to another (Palumbo et al., 2015), students may generalize the meaning of Greek and Latin roots to unknown words, which enables the growth of their domain-specific academic vocabulary (White et al., 1989). Greek and Latin roots' knowledge was also found to contribute to vocabulary, specifically academic vocabulary, among elementary and high school students (Crosson \& Moore, 2017; Crosson et al., 2019).

Because of the higher proportion of Greek and Latin roots' words in French compared to English (90\% vs. 60-75\%; Bertrand, 2011; Rasinski et al., 2008; Stockwell \& Minkova, 2001), vocabulary and Greek and Latin roots' knowledge seem to be sharing the contribution to reading comprehension in French more than in English. Meanwhile, the hypothesis of this shared contribution led us to wonder if they are different dimensions of the same construct or if they are two different constructs. As such, our data reminds us of a similar debate about the separability of morphological awareness and vocabulary. Mitigated results from different studies suggest that morphological awareness and vocabulary might be two dimensions of the same construct (Tannenbaum et al., 2006) or two different constructs (Kieffer \& Lesaux, 2012; Shahar-Yames et al., 2018). It would then be of interest to investigate the separability of the knowledge of Greek and Latin roots from vocabulary knowledge in future studies in different linguistic contexts.

Another possible explanation for this close relationship between the knowledge of Greek and Latin roots and vocabulary observed in our study could rely on the composition of the knowledge of Greek and Latin roots' test itself. Effectively, it is worth repeating that in this test students were asked to choose the right meaning of the root among four choices. Thus, this test includes a semantic aspect that is specific to vocabulary. It is therefore likely that the vocabulary breadth test measures some aspects of semantic knowledge already measured by the knowledge of Greek and Latin roots' test.

\section{Limitations}

Some limitations of the study need to be considered. The most important limitation lies in the small sample of the study. Considering the numerous control variables of this study (i.e., morphological awareness, vocabulary breadth, oral comprehension, long word fluency, and working memory), the results may lack statistical power.

Also, word frequency was considered while designing the knowledge of Greek and Latin roots' test instead of the root frequency. Effectively, it is recommended to also consider root frequency and even morphological family breadth because they are likely to support learning of new words by allowing more encounters with the root in many 
different contexts (Ford et al., 2010). For example, the item rehydrate was considered to be rare in textbooks (Lété et al., 2004). However, the root $h y d r(o)$ is highly productive. An analysis of the root frequency might explain the low success rate on the test measuring the knowledge of Greek and Latin roots since frequent roots are more likely to be known than rare ones.

\section{Conclusion and Implications of the Study}

Our results on the relationship between the knowledge of Greek and Latin roots and reading comprehension have some implications for practitioners and researchers. Since a relationship between Greek and Latin roots, reading comprehension, and vocabulary has been shown, it might be of interest for teachers to consider the richness of Greek and Latin roots in the teaching of domain-specific academic vocabulary and expository texts. It is increasingly recognized that reading has a key role in scholastic and social success. A known phenomenon in education, the $4^{\text {th }}$-grade crisis, is, among others, characterized by a salient drop in $4^{\text {th }}$-grade students' performance in reading (Snow et al., 2005). This issue seems to persist through $6^{\text {th }}$ grade (the last year of elementary school in the province of Quebec, Canada) since, one francophone $6^{\text {th }}$ grader out of four experiences reading comprehension difficulties and doesn't reach the passing score on their final elementary school exam in reading (Desrosiers \& Tétreault, 2012). This difficulty mainly lies in expository texts (Progress in International Reading Literacy Study [PIRLS], 2011) and lexical knowledge of infrequent words (Daussin et al., 2011). Considering that students' performance regarding domain-specific academic vocabulary knowledge influences school success (Palumbo et al., 2015), the results of the present study are of interest.

In a francophone context, particularly in Quebec, there are no requirements in the curriculum to study Greek and Latin roots. But, starting in Grade 6, there is a suggestion to discover the meaning of some Greek and Latin roots. However, we don't know if teachers are informed on how to teach those roots and what is being taught. While, in the middle grades, reading instruction evolves from learning to read to reading for learning (Chall, 1983), instruction of Greek and Latin roots would benefit as early as elementary school to develop autonomy in reading strategies. Intervention on Greek and Latin roots composing domain-specific academic vocabulary could be conceived based on Marzano's (2020) six steps: 1) Describe the root/word; 2) Ask the students to describe or define the root/word in their own words; 3) Ask the students to describe the root/word in a non-linguistic way (image, symbol, etc.); 4) Engage students in activities with the root/word; 5) Ask students to have a discussion about the root/word; 6) Allow time to play with the root/word. For example, in a discovery activity, teachers could ask their students to find the common concept among a variety of target words: hydroelectricity, hydrophobia, hydrography, and hydroplane. The teacher could then organize a friendly competition where two groups are asked to find the largest morphological family for the target root $h y d r(o)$. An integration activity could be creating neologism using taught Greek and Latin roots and explaining their meaning: hydrovorous is the characteristic of an entity subsisting only by consuming/eating water. Activities with Greek and Latin roots are of infinite possibilities and engage students in playful learning situations. A research-based program on Greek and Latin roots instruction needs to be designed and tested in ecological contexts so that teachers and students could benefit from it. 
We are aware that our results are not representing a causal relationship between Greek and Latin roots knowledge and reading comprehension. However, based on the significant correlation between Greek and Latin roots' knowledge, reading comprehension and vocabulary obtained in our results and on extant results in an English context, an effective and robust instruction on Greek and Latin roots may help children to enhance reading comprehension, especially sentence comprehension (Crosson \& McKeown, 2016; Crosson et al., 2019), and academic vocabulary development (Crosson \& Moore, 2017; Crosson et al., 2019).

Elsewhere, the present study has some implications for future research. Lists of Greek and Latin roots are available both in English (e.g., Green, 2015; Rasinski et al., 2008) and French (e.g., Cellard, 2013), but we do not know the proportion of these roots in student schoolbooks in French. Further studies should index the most productive Greek and Latin roots by grade level, but also by school subject in order to guide elementary school and high school teachers in selecting Greek and Latin roots for instruction. Also, since the proportion of domain-specific academic vocabulary is more important in expository texts (Bar-ilan \& Berman, 2007; Green, 2015), it would be interesting to measure the relationship between knowledge of Greek and Latin roots and reading comprehension among those texts. Additionally, future research is needed to verify the effects of Greek and Latin roots instruction on domain-specific academic vocabulary and reading comprehension of disciplinary texts among francophone students. Such findings would nourish reading comprehension models with results in a new linguistic context in addition to those in an English context (Crosson \& McKeown, 2016; Crosson \& Moore, 2017; Crosson et al., 2019).

\section{Funding}

This study received support from the Social Sciences and Humanities Research Council of Canada (SSHRC) by means of the Canada Graduate Scholarships-Master's Program (CGS M) and also from the Fonds de recherche du Québec - Société et culture (FRQSC) (\#197499) which granted to the first author with master's Research Scholarships.

\section{References}

Anctil, D., Singcaster, M., \& Tardif, M. (2018). Pratiques d'enseignement du lexique en classe de primaire au Québec [Teaching practices of lexicon in primary class in Quebec]. La lettre, 64, 19-25. https://doi.org/10.3406/airdf.2018.2247

Bar-ilan, L., \& Berman, R. A. (2007). Developing register differentiation: The Latinate-Germanic divide in English. Linguistics, 45(1), 1-35. https://doi.org/10.1515/LING.2007.001

Baumann, J. F., \& Graves, M. F. (2010). What is academic vocabulary? Journal of Adolescent \& Adult Literacy, 54(1), 4-12. https://doi.org/10.1598/JAAL.54.1.1

Bertrand, O. (2011). Histoire du vocabulaire français [History of French vocabulary]. Éditions de l'école Polytechnique.

Bianco, M., Colé, P., Lima, L., Mgherbi, P., Nardy, A., Rocher, T., \& Sprender-Charolles, L. (2014, September 30). Évaluation diagnostique chez les élèves pour 9 à 11 ans [Diagnostic assessment among 9 to 11 years old students] [Paper presentation]. Matinée d'échanges sur un sujet actuel, Université du Québec à Montréal, Montreal, Canada. 
Blachowicz, C. L. Z., \& Obrochta, C. (2005). Vocabulary visits: Virtual field trips for content vocabulary development. The Reading Teacher, 59(3), 262-268.

https://doi.org/10.1598/RT.59.3.6

Bowers, P. N., Kirby, J. R., \& Deacon, S. H. (2010). The effects of morphological instruction on literacy skills: A systematic review of the literature, Review of Educational Research, 80(2), 144-179. https://doi.org/10.3102/0034654309359353

Carlisle, J. F. (2000). Awareness of the structure and meaning of morphologically complex words: Impact on reading. Reading and Writing, 12, 169-190. https://doi.org/10.1023/A:1008131926604

Casalis, S., \& Janiot, M. (2009). Reconnaissance de mots écrits chez les enfants dyslexiques et normolecteurs: effets du voisinage orthographique [Written words recognition among dyslexics children and typically developped readers: Effects of orthographic neighborhood]. In N. Marec-Breton, A.-S. Besse, F. De La Haye, N. Bonneton-Botté, \& E. Bonjour (Eds.), L'apprentissage de la langue écrite (pp. 67-79). Presses universitaires de Rennes.

Casalis, S., \& Louis-Alexandre, M.-F. (2000). Morphological analysis, phonological analysis and learning to read French: a longitudinal study. Reading and Writing, 12, 303-335. https://doi.org/10.1023/A:1008177205648

Cellard, J. (2013). Les racines grecques et latines du vocabulaire français [Greek and Latin roots of French vocabulary]. De Boeck Supérieur.

Chall, J. S. (1983). Stages of Reading Development. McGraw-Hill Book Company.

Crosson, A. C., \& McKeown, M. G. (2016). Middle school learners' use of Latin roots to infer the meaning of unfamiliar words. Cognition and Instruction, 34(2), 148-171. https://doi.org/10.1080/07370008.2016.1145121

Crosson, A. C., McKeown, M. G., Moore, D. W., \& Ye, F. (2019). Extending the bounds of morphology instruction: teaching Latin roots facilitates academic word learning for English Learner adolescents. Reading and Writing, 32(3), 689-727. https://doi.org/10.1007/s11145-018-9885-y

Crosson, A. C., \& Moore, D. (2017). When to take up roots: The effects of morphology instruction for middle school and high school English learners. Reading Psychology, 38(3), 262-288. https://doi.org/10.1080/02702711.2016.1263699

Daniels, H. (2002). Expository text in literature circles. Voices from the Middle, 9(4), 7-14. http://oldmoodle.escco.org/file.php/1/READING/expository_text.pdf

Daussin, J.-M., Keskpaik, S., \& Rocher, T. (2011). L'évolution du nombre d'élèves en difficulté face à l'écrit depuis une dizaine d'années [The evolution of the number of students in writting difficulty from a decade]. France, portrait social, 137-152. https://www.insee.fr/fr/statistiques/1373895?sommaire=1373905

Deacon, S. H., Francis, K., \& Tong, X. (2017). The relationship of morphological analysis and morphological decoding to reading comprehension. Journal of Research in Reading, 40(1), 1-16. https://doi.org/10.1111/1467-9817.12056

Desrosiers, H., \& Tétreault, K. (2012). Les facteurs liés à la réussite aux épreuves obligatoires de français en sixième année du primaire: un tour d'horizon [Factors associated with success in compulsory French exams in grade 6 of elementary school: An overview]. Québec Government, Institut de la statistique.

https://www.stat.gouv.qc.ca/statistiques/education/prescolaire-primaire/reussite-epreuvefrancais.pdf 
Dunn, L. M., Dunn, L. M., \& Theriault-Whalen, C. M. (1993). ÉVIP: Échelle de vocabulaire en images Peabody [Peabody Picture Vocabulary Test] (revised edition). Psycan.

Fazio, X., \& Gallagher, T. L. (2014). Morphological development levels of science content vocabulary: Implications for science-based texts in elementary classrooms. International Journal of Science and Mathematics Education, 12, 1407-1423. https://doi.org/10.1007/s10763-013-9470-4

Fejzo, A. (2016). The contribution of morphological awareness to the spelling of morphemes and morphologically complex words in french. Reading and Writing, 29(2), 207-228. https://doi.org/10.1007/s11145-015-9586-8

Ford, M. A., Davis, M. H., \& Marslen-Wilson, W. D. (2010). Derivational morphology and base morpheme frequency. Journal of Memory and Language, 63(1), 117-130. https://doi.org/10.1016/j.jml.2009.01.003

Freeman, N.D., Townsend, D., \& Templeton, S. (2019). Thinking about words: First graders' response to morphological instruction. The Reading Teacher, 72(4), 463-473. https://doi.org/10.1002/trtr.1749

Gough, P. B., \& Tunmer, W. E. (1986). Decoding, reading, and reading disability. Remedial and Special Education, 7(1), 6-10. https://doi.org/10.1177/074193258600700104

Green, T. M. (2015). The Greek and Latin roots of English ( $5^{\text {th }}$ ed.). Rowman \& Littlefield.

Henry, M. (2010). Unlocking literacy: Effective decoding and spelling instruction ( $2^{\text {nd }}$ ed.). Brookes.

Howell, D. C. (2008). Méthodes statistiques en sciences humaines [Statistical methods in social sciences] (2nd ed.). De Boeck.

Kieffer, M. J., \& Box, C. D. (2013). Derivational morphological awareness, academic vocabulary, and reading comprehension in linguistically diverse sixth graders. Learning and Individual Differences, 24, 168-175. https://doi.org/10.1016/j.lindif.2012.12.017

Kieffer, M. J., \& Lesaux, N. K. (2012). Knowledge of words, knowledge about words: Dimensions of vocabulary in first and second language learners in sixth grade. Reading and Writing, 25, 347-373. https://doi.org/10.1007/s11145-010-9272-9

Kintsch, W. (1998). Comprehension, a paradigm for cognition. Cambridge University Press.

Kirby, J. R., Deacon, S. H., Bowers, P. N., Izenberg, L., Wade-Woolley, L., \& Parrila, R. (2012). Children's morphological awareness and reading ability. Reading and Writing, 25, 389410. https://doi.org/10.1007/s11145-010-9276-5

Kuo, L.-j., \& Anderson, R. C. (2006). Morphological awareness and learning to read: A crosslanguage perspective. Educational Psychologist, 41(3), 161-180. https://doi.org/10.1207/s15326985ep4103_3

Lété, B., Sprenger-Charolles, L., \& Colé, P. (2004). MANULEX: A grade-level lexical database from French elementary-school readers. Behavior Research Methods, Instruments, \& Computers, 36, 156-166. https://doi.org/10.3758/BF03195560

Levesque, K. C., Kieffer, M. J., \& Deacon, S. H. (2017). Morphological awareness and reading comprehension: Examining mediating factors. Journal of Experimental Child Psychology, 160, 1-20. https://doi.org/10.1016/j.jecp.2017.02.015

Mousty, P., Leybaert, J., Alegria, J., Content, A., \& Morais, J. (1994). BELEC. Batterie d'évaluation du langage écrit et de ses troubles [Assessment battey of written language]. In J. Grégoire \& B. Piérart (Eds.), Évaluer les troubles de la lecture : Les nouveaux modèles théoriques et leurs implications diagnostiques (pp. 127-145). De Boeck. 
Nagy, W., \& Anderson, R. C. (1984). How many words are there in printed school English? Reading Research Quarterly, 19(3), 304-330. https://doi.org/10.2307/747823

Nagy, W., Berninger, V. W. et Abbott, R. D. (2006). Contributions of morphology beyond phonology to literacy outcomes of upper elementary and middle-school students. Journal of Educational Psychology, 98(1), 134-147. https://doi.org/10.1037/0022-0663.98.1.134

Nagy, W. E., Anderson, R. C., \& Herman, P. A. (1987). Learning word meanings from context during normal reading. American Educational Research Journal, 24(2), 237-270. https://doi.org/10.3102/00028312024002237

Nagy, W., \& Townsend, D. (2012). Words as tools: Learning academic vocabulary as language acquisition. Reading Research Quarterly, 47(1), 91-108. https://doi.org/10.1002/RRQ.011

Nation, I. S. P. (2006). How large a vocabulary is needed for reading and listening? The Canadian Modern Language Review, 63(1), 59-82. https://doi.org/10.1353/cml.2006.0049

National Reading Panel. (2000). Teaching children to read: An evidence-based assessment of the scientific research literature on reading and its implications for reading instruction. https://www.nichd.nih.gov/sites/default/files/publications/pubs/nrp/Documents/report.pdf

Nunes, T., Bryant, P., \& Barros, R. (2012). The development of word recognition and its significance for comprehension and fluency. Journal of Educational Psychology, 104(4), 959-973. https://doi.org/10.1037/a0027412

Observatoire National de la Lecture. (2000). Maîtriser la lecture [Master reading]. Odile Jacob.

Padak, N., Newton, E., Rasinski, T., \& Newton, R. M. (2008). Getting to the root of word study: Teaching Latin and Greek word roots in elementary and middle grades. In A. E. Farstrup \& S. J. Samuels (Eds.), What research has to say about vocabulary instruction. International Reading Association.

Palumbo, A., Kramer-Vida, L., \& Hunt, C. V. (2015). Teaching vocabulary and morphology in intermediate grades. Preventing School Failure: Alternative Education for Children and Youth, 59(2), 109-115. https://doi.org/10.1080/1045988X.2013.850649

Perfetti, C. A. (1985). Reading ability. Oxford University Press.

Perfetti, C. (2007). Reading ability: Lexical quality to comprehension. Scientific Studies of Reading, 11(4), 357-383. https://doi.org/10.1080/10888430701530730

Perfetti, C., \& Stafura, J. (2014). Word knowledge in a theory of reading comprehension. Scientific Studies of Reading, 18(1), 22-37. https://doi.org/10.1080/10888438.2013.827687

Progress in International Reading Literacy Study. (2011). PIRLS 2011 International Results in Reading. TIMSS \& PIRLS International Study Center. https://timssandpirls.bc.edu/pirls2011/international-results-pirls.html

Rasinski, T. V., Padak, N., Newton, R. M., \& Newton, E. (2008). Greek and Latin roots: Keys to building vocabulary. Shell Education.

Shahar-Yames, D., Eviatar, Z., \& Prior, A. (2018). Separability of lexical and morphological knowledge: Evidence from language minority children. Frontiers in Psychology, 9. https://doi.org/10.3389/fpsyg.2018.00163

Singson, M., Mahony, D., \& Mann, V. (2000). The relation between reading ability and morphological skills: Evidence from derivational suffixes. Reading and Writing, 12(3), 219-252. https://doi.org/10.1023/A:1008196330239

Snow, C. E., Griffin, P., \& Burns, S. M. (2005). Knowledge to support the teaching of reading: preparing teachers for a changing world. Jossey-Bass.

Stockwell, R., \& Minkova, D. (2001). English words: History and structure. Cambridge University Press. 
Tannenbaum, K.R., Torgesen, J.K., \& Wagner, R.K. (2006). Relationships between word knowledge and reading comprehension in third-grade children. Scientific Studies of Reading, 10(4), 381-398. https://doi.org/10.1207/s1532799xssr1004_3

Tunmer, W. E., \& Chapman, J. W. (2012). The simple view of reading redux: Vocabulary knowledge and the independent components hypothesis. Journal of Learning Disabilities, 45(5), 453-466. https://doi.org/10.1177/0022219411432685

Uccelli, P., Galloway, E. P., Barr, C. D., Meneses, A., \& Dobbs, C. L. (2015). Beyond vocabulary: Exploring cross-disciplinary academic-language proficiency and its association with reading comprehension. Reading Research Quarterly, 50(3), 337-356. https://doi.org/10.1002/rrq.104

Wechsler, D. (2008). WIAT-II Test de rendement individuel de Wechsler [WIAT-II Wechsler's individual performance test] (2nd ed., French Canadian version). Pearson Canada Assessment.

White, T. G., Power, M. A., \& White, S. (1989). Morphological analysis: Implications for teaching and understanding vocabulary growth. Reading Research Quarterly, 24(3), 283-304. https://doi.org/10.2307/747771

Wiig, E., Secord, W., \& Semel, E. (adapted by Boulianne, L., \& Labelle, M). (2009). Évaluation clinique des notions langagières fondamentales: Version pour francophones du Canada [Clinical evaluation of language fundamentals: French Canadian version]. Pearson Canada Assessment. 